\title{
PENGARUH PEMBERIAN STRESS OSMOTIK TERHADAP KADAR TOTAL LIPID MIKROALGA Porphyridium sp. DAN Isochrysis sp. PADA SALINITAS YANG BERBEDA
}

\section{THE EFFECT OF GIVING OSMOTIC STRESS TOWARD THE LEVEL OF LIPID TOTAL OF Porphyridium sp. AND Isochrysis sp. MICROALGAE AT DIFFERENT SALINITY}

\author{
Lia Anggraini $i^{*}$, Endang Linirin Widiastuti ${ }^{1}$, Sri Murwani ${ }^{1}$ \\ 1Jurusan Biologi FMIPA Universitas Lampung \\ Jl. Prof. Dr. Soemantri Brodjonegoro No.1 Bandar Lampung 35145 \\ "e-mail : anggraini.la@gmail.com
}

\begin{abstract}
ABSTRAK
Mikroalga merupakan salah satu produsen primer yang diduga memiliki kandungan lipid tinggi untuk dimanfaatkan sebagai energi alternatif. Mikroalga yang memiliki kandungan lipid cukup tinggi diantaranya adalah Porphyridium sp. dan Isochrysis sp. Pemberian stress osmotik diduga dapat meningkatkan kadar total lipid mikroalga Porphyridium sp. dan Isochrysis sp. Penelitian ini bertujuan untuk mengetahui pengaruh pemberian stress osmotik berupa perbedaan salinitas terhadap kadar total lipid pada mikroalga Porphyridium sp. dan Isochrysis sp. Penelitian ini telah dilaksanakan pada bulan Januari - Februari 2016 di Laboratorium Biologi Molekuler Jurusan Biologi Fakultas Matematika dan IImu Pengetahuan Alam Universitas Lampung. Penelitian ini menggunakan Rancangan Acak Lengkap dengan faktorial yang terdiri dari 2 jenis mikroalga serta 4 taraf salinitas 20 ppt, 25 ppt, 30 ppt, dan 35 ppt, serta 3 kali ulangan. Parameter yang diamati yaitu kepadatan populasi, laju pertumbuhan, dan kadar total lipid. Data dianalisis dengan Analysis of Variance (ANOVA) dan diuj lanjut dengan Uji Tukey HSD pada taraf $5 \%$. Hasil penelitian menunjukkan bahwa kepadatan populasi tertinggi terjadi pada perlakuan Isochrysis sp. pada salinitas 35 ppt. Mikroalga yang menyumbang lipid tertinggi pada tiap selnya adalah Porphyridium sp. pada salinitas $20 \mathrm{ppt}$ sebesar $6 \times 10^{-6} \mathrm{~g} / \mathrm{sel}$ dan Isochrysis sp. pada salinitas $20 \mathrm{ppt}$ sebesar $45 \times 10^{-7} \mathrm{~g} / \mathrm{sel}$.
\end{abstract}

Kata Kunci: Porphyridium, Isochrysis, salinitas, stress osmotik, kadar total lipid

\begin{abstract}
Microalgae is one of the primary producers that presumably have high lipid contents used as an alternative energy. Microalgae which have sufficient high lipid contents are Porphyridium sp. and Isochrysis sp. It was expected that giving osmotic stress to microalgae Porphyridium sp. and Isochrysis sp. may increase the level of lipid total themselves. This research purposed to determine giving osmotic stress in different salinity levels to the total lipid content of microalgae Porphyridium sp. and/sochrysis sp. This research was conducted on January until February 2016 in Biomolecular Laboratory, Department of Biology, Mathematics and Natural Sciences Faculty, University of Lampung. This experiment were using complete randomized design with factorial within two species of microalgae and four levels of salinity namely 20 ppt, $25 \mathrm{ppt}, 30 \mathrm{ppt}$, and $35 \mathrm{ppt}$ with three replicantions. Observed parameters are population density, growth rate, and the level of lipid total. Data were analyzed by using Analysis of Variant (Anova) and advanced test using Tukey - HSD Test with significance level at $a=5 \%$. The result showed that the highest level of lipid total is Isochrysis sp. with treatment $35 \mathrm{ppt}$ of salinity. Microalgae that contribute the highest level of lipid total each cell is Porphyridium sp. with treatment $20 \mathrm{ppt}$ of salinity are $6 \times 10^{-6} \mathrm{~g} / \mathrm{cell}$ and Isochrysis sp. with treatment $20 \mathrm{ppt}$ of salinity $45 \times 10^{-7} \mathrm{~g} / \mathrm{cell}$.
\end{abstract}

Keywords: Porphyridium, Isochrysis,salinity, osmotic stress, the level of lipid total 


\section{PENDAHULUAN}

Mikroalga merupakan mikroorganisme bersel tunggal yang berbentuk seperti benang. Hidupnya melayang-layang di dalam air dan keberadaannya sangat dipengaruhi oleh gerakan air (Davis, 1951). Alga sangat berperan penting sebagai produsen primer. Hal ini karena mikroalga memiliki kemampuan untuk berfotosintesis dengan cara mengubah sinar matahari, air, dan karbondioksida menjadi energi seperti layaknya tumbuhan tingkat tinggi (Kawaroe, 2010). Pertumbuhan dari Porphyridium sp. sendiri bergantung pada ketersediaan nutrien, suhu, intensitas cahaya, $\mathrm{pH}$, karbondioksida, dan salinitas (Sleigh, 1989).

Porphyridium sp. merupakan mikroalga yang memiliki kecepatan pertumbuhan tinggi dan masa panennya cepat, memiliki kandungan asam lemak tinggi, bersifat dapat terbaharukan dan ramah lingkungan sehingga berpotensi untuk dikembangkan sebagai biodiesel (Kabinawa, 2005). Selain Porphyridium sp. terdapat mikroalga yang diduga mengandung lipid yang cukup tinggi, salah satunya yaitu Isochrysis sp. (Christi, 2007).

Lipid merupakan sejumlah senyawa yang terdapat di alam. Lipid sukar larut atau tidak dapat larut dalam air, namun dapat larut dalam pelarut organik non polar seperti pentana, benzen, dietil eter, alkohol dan kloroform. Lipid memiliki fungsi biologis sebagai komponen struktural membran serta penyimpanan energi (Panggalo, 2012).
Pertumbuhan dan perkembangan mikroalga Porphyridium sp. dan Isochrysis sp. dipengaruhi oleh beberapa faktor, salah satunya adalah salinitas. Salinitas atau kadar garam dapat mempengaruhi pertumbuhan dan perkembangan mikroalga. Salinitas yang tidak sesuai, berpengaruh langsung terhadap kelangsungan hidup dan tingkat pertumbuhannya (Odum, 1993). Kondisi lingkungan dan tempat tumbuh mikroalga yang tidak sesuai berpengaruh terhadap kandungan lipid mikroalga tersebut. Saat mikroalga mengalami tekanan, akumulasi lipid cenderung mengalami peningkatan (Kawaroe et al., 2010). Hal ini merupakan bentuk adaptasi yang dilakukan organisme terhadap salinitas yang tidak optimal untuk tumbuh sehingga cenderung tidak mengeluarkan banyak energi. Perbedaan salinitas ini berpengaruh terhadap tekanan osmosis dan mekanisme osmoregulasi yang bertujuan untuk menyamakan konsentrasi garam internal dengan konsentrasi garam yang berada di lingkungan luar (Widianingsih, 2011). Pada kondisi tidak normal, mikroalga tetap berfotosintesis dengan bantuan $\mathrm{CO}_{2}$ dan mengakumulasi hasilnya dalam bentuk karbohidrat dan lipid (Schenk et.al, 2008). Penelitian ini dilakukan untuk mengetahui pengaruh pemberian stress osmotik terhadap kadar total lipid mikroalga Porphyridium sp. dan Isochrysis sp. pada salinitas yang berbeda. 


\section{BAHAN DAN METODE}

\section{Bahan}

Penelitian ini dilaksanakan pada bulan Januari sampai Februari 2016 di Laboratorium Biologi Molekuler Jurusan Biologi Fakultas Matematika dan IImu Pengetahuan Alam Universitas Lampung. Bahan-bahan yang digunakan dalam penelitian yaitu air laut steril, air tawar steril, mikroalga uji Porphyridium sp. dan Isochrysis sp. yang didapat dari Laboratorium Pakan Alami Balai Besar Perikanan Budidaya Laut Lampung, Pupuk Conwy, Garam Krosok, Formalin, Kaporit, Alkohol $70 \%, \mathrm{NaOH}$, Aquades, Kloroform, dan Metanol untuk proses ekstraksi pengukuran kadar total lipid mikroalga.

\section{Metode Penelitian}

Penelitian ini menggunakan rancangan acak lengkap (RAL) dengan faktorial yang terdiri dari 2 jenis mikroalga, Porphyridium sp. dan Isochrysis sp. masing masing pada level salinitas 20 ppt, 25 ppt, 30 ppt, dan 35 ppt.

Kultur kedua mikrolaga pada salinitas yang berbeda tersebut dilakukan selama 8 hari dan dihitung kepadatannya setiap hari dengan menggunakan alat haemocytometer di bawah mikroskop. Adapun rumus kepadatan sel menurut Mudjiman (2007) adalah sebagai berikut:

$$
\Sigma \mathrm{Sel} / \mathrm{ml}=\mathrm{N} \times 10^{4}
$$

Keterangan:

$\mathrm{N}: \quad$ Jumlah rata-rata sel
Setelah didapatkan nilai kepadatannya kemudian dihitung laju pertumbuhan spesifik menggunakan rumus modifikasi menurut Becker (1994) yaitu:

$$
\mu=\frac{\text { LnNt }- \text { LnNo }}{t} \times 100 \%
$$

\section{Keterangan :}

No : Kepadatan awal populasi (Ind/L)

$\mathrm{Nt} \quad$ : Kepadatan puncak populasi (Ind/L)

t : Waktu (hari)

$\mu \quad$ : Laju Pertumbuhan Populasi (\%/hari)

\section{Ekstraksi Lipid}

Ekstraksi dilakukan dengan cara mensentrifugasi hasil kultur untuk memisahkan mikroalga dengan air pelarutnya. Setelah mengendap, air pelarutnya dibuang untuk mendapatkan mikroalga basah berbentuk natan. Natan yang telah terpisah tersebut kemudian ditimbang sebanyak $3 \mathrm{~g}$. Tahap selanjutnya adalah menguji kandungan lipid dengan menggunakan metanol dan kloroform dengan perbandingan $1: 1(1 \mathrm{ml}: 1 \mathrm{ml})$ lalu dihomogenkan selama kurang lebih 1 menit kemudian didiamkan di dalam kulkas selama 15 menit. Setelah didiamkan, natan tersebut diberi akuades $1 \mathrm{ml}$ lalu kemudian disentrifugasi hingga terpisah larutan lipidnya. Lipid tersebut diambil dan ditaruh di cawan petri steril untuk dikeringkan. Setelah itu tahap selanjutnya dilakukan evaporasi atau dikeringkan menggunakan alat desikator kemudian dilakukan penimbangan. Padatan yang telah kering ini sebagai hasil perhitungan kadar total lipid. Lipid yang telah diketahui berat 
keringnya kemudian dilarutkan kembali menggunakan akuades untuk diukur dengan spektrofotometer menggunakan panjang gelombang $680 \mathrm{~nm}$ (Wayan et al, 2012). Data dianalisis dengan one way Anova dan dilakukan uji lanjut dengan Uji Tukey HSD.

\section{HASIL DAN PEMBAHASAN}

Hasil

\section{Kepadatan Populasi}

Kultur mikroalga skala laboratorium dilakukan selama 8 hari. Kepadatan populasi dihitung setiap hari hingga akhir pengkulturan. Dari perhitungan kepadatan didapatkan data seperti yang disajikan pada tabel 1 sebagai berikut :

Tabel 1. Kepadatan populasi malga pada salinitas berbeda (Ind/ml)

\begin{tabular}{|c|c|c|c|c|c|c|c|c|}
\hline \multirow{3}{*}{$\begin{array}{c}\text { Hari } \\
\text { ke }\end{array}$} & \multicolumn{8}{|c|}{ Jenis mikroalga / salinitas } \\
\hline & \multicolumn{4}{|c|}{ Porphyridium sp } & \multicolumn{4}{|c|}{ Isochrysis sp } \\
\hline & 20 ppt & 25 ppt & 30 ppt & 35 ppt & 20 ppt & 25 ppt & 30 ppt & 35 ppt \\
\hline 1 & $1500 \pm 0^{\mathrm{a}}$ & $1500 \pm 0^{a}$ & $1500 \pm 0^{a}$ & $1500 \pm 0^{a}$ & $2000 \pm 0^{a}$ & $2000 \pm 0^{a}$ & $2000 \pm 0^{a}$ & $2000+0^{a}$ \\
\hline 2 & $953 \pm 89^{c}$ & $1232 \pm 138$ & $1570 \pm 18^{b}$ & $1563 \pm 24$ & $2233_{\frac{a}{a}} 14$ & $2358 \pm 142$ & $2217 \pm 176$ & $2408 \pm 188$ \\
\hline 3 & $708 \pm 81^{c}$ & $935 \pm 74^{c}$ & $1630 \pm 5^{b}$ & $1608 \pm 36^{b}$ & $2467 \underset{\mathrm{a}}{ \pm 184}$ & $2525 \pm 75$ & $2525 \pm 241^{a}$ & $2667 \pm \frac{ \pm}{a} 142$ \\
\hline 4 & $533 \frac{ \pm}{d} 104$ & $700 \pm 156^{c d}$ & $1385_{b c}+152$ & $1653 \pm 28$ & $1967 \underset{b}{ \pm 593}$ & $1902 \underset{b}{ \pm 258}$ & $2750 \pm \frac{ \pm}{a} 241$ & $2887 \pm \frac{ \pm}{a} 137$ \\
\hline 5 & $370+\frac{ \pm}{b} 133$ & $467 \pm 178^{b}$ & $1005 \pm \frac{ \pm}{b} 161$ & $1530 \frac{+}{b} 289$ & $1317_{\frac{\mathrm{b}}{\mathrm{b}}} 401$ & $1325 \pm 25$ & $2760 \pm \frac{ \pm}{a} 910$ & $2853_{a} \pm 568$ \\
\hline 6 & $193 \pm 65^{b}$ & $328 \pm 136^{b}$ & $775 \pm 152^{b}$ & $1220 \pm \frac{a b}{220}$ & $900 \frac{ \pm}{b} 327$ & $767 \frac{ \pm}{b} 250$ & $2170 \pm \frac{ \pm}{a} 930$ & $2483_{a}+726$ \\
\hline 7 & $115 \pm 10^{c}$ & $180 \pm 72^{c}$ & $475 \pm 109^{b c}$ & $945 \underset{\mathrm{abc}}{ \pm} 157$ & $250 \pm 175^{c}$ & $408 \frac{ \pm}{\mathrm{bc}} 404$ & $1708+969$ & $1903_{\frac{a}{a}} 871$ \\
\hline 8 & $50 \pm 0^{b}$ & $75 \pm 25^{b}$ & $175 \pm 25^{a b}$ & $583+339$ & $67 \pm 29^{b}$ & $125+\frac{+}{b} 109$ & ${ }_{\mathrm{ab}} 1067+682$ & $1200 \pm \frac{ \pm}{a} 736$ \\
\hline
\end{tabular}

Keterangan :

- Angka pada baris yang sama diikuti dengan huruf superscriptyang sama tidak berbeda nyata padataraf $\alpha=0,05$

- Angka yang diarsir menunjukkan kepadatan tertinggi

Tabel 1 menunjukkan kepadatan puncak terjadi pada hari yang berbeda pada masing-masing perlakuan. Perlakuan Porphyridium sp. pada salinitas 20 ppt dan salinitas 25 ppt tidak mengalami peningkatan pada hari kedua. Namun pada salinitas 30 ppt memiliki tingkat kepadatan yang berbeda nyata dibandingkan pada salinitas lebih rendah yaitu salinitas 20 ppt dan salinitas 25 ppt, serta pada salinitas 30 ppt dan pada salinitas 35 ppt pada hari ke4. Demikian pula untuk perlakuan Isochrysis sp., puncak kepadatan populasi pada media kultur terjadi di hari ke 4 dan pada salinitas yang tinggi yaitu pada salinitas 35 ppt dan salinitas 35 ppt.

\section{Laju Pertumbuhan}

Hasil pengukuran rata-rata laju pertumbuhan dari mikroalga Porphyridium sp. dan Isochrysis sp. yang diberi perlakuan salinitas yang berbeda disajikan pada Gambar 1 


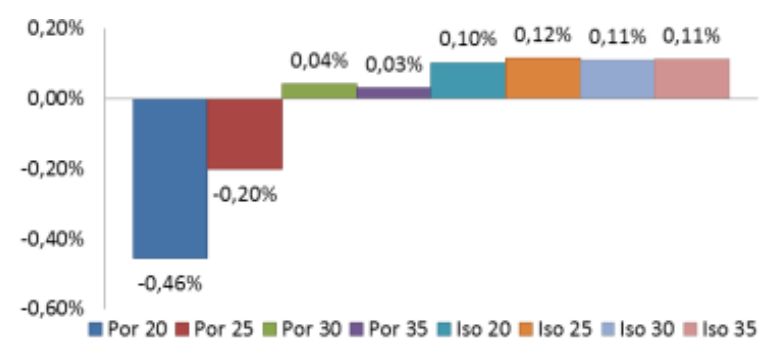

Gambar 1. Rata-rata laju pertumbuhan mikroalga (\%). Por = Porphyridium $\mathrm{sp}$. dan Iso = Isochrysis sp.

Gambar 1 menunjukkan rata-rata laju pertumbuhan spesifik. Terdapat dua perlakuan yang laju pertumbuhannya sangat rendah atau di bawah $0 \%$, yaitu pada perlakuan Porphyridium sp. pada salinitas 20 ppt dan perlakuan Porphyridium sp. pada salinitas 25 ppt. Hal ini menunjukkan bahwa pada kedua salinitas tersebut laju kematiannya lebih tinggi dari laju pertumbuhannya. Kemudian pada mikroalga Isochrysis $\mathrm{sp}$. rata-rata laju pertumbuhan tertinggi pada salinitas $25 \mathrm{ppt}$ yaitu sebesar $0,12 \%$.

\section{Kandungan Lipid}

Hasil perhitungan kandungan lipid pada mikroalga Porphyridium sp. dan Isochrysis sp. yang diberi perlakuan salinitas berbeda disajikan pada Gambar 2.

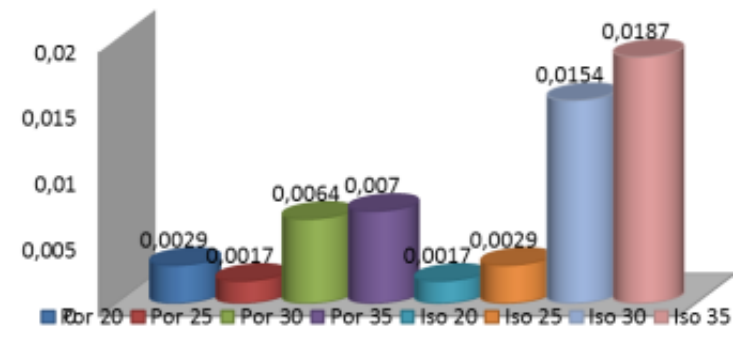

Gambar 2. Berat kering lipid mikroalga (g). Por = Porphyridium sp. dan Iso = Isochrysis sp.

Berat kering lipid tertinggi adalah terjadi pada perlakuan Isochrysis sp. pada salinitas
35 ppt, dan berat kering lipid yang paling rendah terjadi pada dua perlakuan yaitu pada perlakuan Porphyridium sp. pada salinitas 25 ppt dan pada perlakuan Isochrysis sp. salinitas 20 ppt.

Untuk memverifikasi kandungan lipid, maka sample lipid dari masing-masing kelompok mikroalga diuji kandungan lipidnya dengan menggunakan spektrofotometri. Kandungan lipid dengan uji spektrofotometri disajikan pada gambar 3 sebagai berikut :

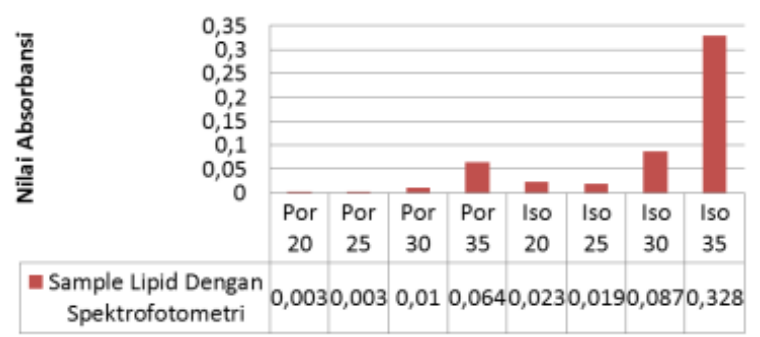

Gambar 3. Sampel lipid menggunakan spektrofotometri (Abs)

Seperti halnya pengukuran kandungan lipid dengan gravimetri (berat kering), nilai tertinggi pengukuran kandungan lipid menggunakan spektrofotometri yaitu pada perlakuan Isochrysis sp. pada salinitas 35 ppt yaitu sebesar 0,328 . Sedangkan nilai terendah pengukuran menggunakan spektrofotometri adalah pada perlakuan Porphyridium sp. pada salinitas 20 ppt dan Porphyridium sp. pada salinitas 25 ppt yaitu sebesar 0,003 .

Jumlah lipid yang telah diketahui dihitung kembali untuk mengetahui perkiraan kandungan lipid yang dihasilkan oleh satu sel. Perkiraan kandungan lipid per sel mikroalga Porphyridium sp. yang dikultur pada salinitas berbeda disajikan pada Tabel 2 . 
Tabel 2. Perkiraan kandungan lipid per sel mikroalga Porphyridium sp. dan Isochrysis sp.

\begin{tabular}{|c|c|c|c|c|}
\hline Perlakuan & Por 20 & Por 25 & Por 30 & Por 35 \\
\hline Kepadatan & $50 \times 10^{4} \mathrm{sel} / \mathrm{ml}$ & $75 \times 10^{4} \mathrm{sel} / \mathrm{ml}$ & $175 \times 10^{4} \mathrm{sel} / \mathrm{ml}$ & $583 \times 10^{4} \mathrm{sel} / \mathrm{ml}$ \\
\hline Berat Kering Lipid & $0,0029 \mathrm{~g}$ & $0,0017 \mathrm{~g}$ & $0,0064 \mathrm{~g}$ & $0,007 \mathrm{~g}$ \\
\hline & $=2,9 \mathrm{mg}$ & $=1,7 \mathrm{mg}$ & $=6,4 \mathrm{mg}$ & $=7 \mathrm{mg}$ \\
\hline Kepadatan terambil & 483 & 425 & 3.733 & $13.603 \mathrm{sel} / \mathrm{ml}$ \\
\hline & $\mathrm{sel} / \mathrm{ml}$ & $\mathrm{sel} / \mathrm{ml}$ & $\mathrm{sel} / \mathrm{ml}$ & \\
\hline Lipid yang dihasilkan 1 & $0,006 \mathrm{mg} / \mathrm{sel}$ & $0,004 \mathrm{mg} / \mathrm{sel}$ & 0,0017 mg/sel & $0,00051 \mathrm{mg} / \mathrm{sel}$ \\
\hline & $=6 \times 10^{-6} \mathrm{~g} / \mathrm{sel}$ & $=4 \times 10^{-6} \mathrm{~g} / \mathrm{sel}$ & $=17 \times 10^{-7} \mathrm{~g} / \mathrm{sel}$ & $=51 \times 10^{-8} \mathrm{~g} / \mathrm{sel}$ \\
\hline Perlakuan & Iso 20 & Iso 25 & Iso 30 & Iso 35 \\
\hline Kepadatan & $66 \times 10^{4} \mathrm{sel} / \mathrm{ml}$ & $125 \times 10^{4} \mathrm{sel} / \mathrm{ml}$ & $\begin{array}{c}1066 \times 10^{4} \\
\mathrm{sel} / \mathrm{ml}\end{array}$ & $1200 \times 10^{4} \mathrm{sel} / \mathrm{ml}$ \\
\hline Berat Kering Lipid & $\begin{array}{l}0,0017 \mathrm{~g} \\
=1,7 \mathrm{mg}\end{array}$ & $\begin{array}{l}0,0029 \mathrm{~g} \\
=2,9 \mathrm{mg}\end{array}$ & $\begin{array}{r}0,0154 \mathrm{~g} \\
=15,4 \mathrm{mg}\end{array}$ & $\begin{array}{c}0,0187 \mathrm{~g} \\
=18,7 \mathrm{mg}\end{array}$ \\
\hline Kepadatan terambil & $\begin{array}{c}374 \\
\mathrm{sel} / \mathrm{ml}\end{array}$ & $1.208 \mathrm{sel} / \mathrm{ml}$ & $54.741 \mathrm{sel} / \mathrm{ml}$ & $74.800 \mathrm{sel} / \mathrm{ml}$ \\
\hline $\begin{array}{l}\text { Lipid yang dihasilkan } 1 \\
\text { sel }\end{array}$ & $\begin{array}{l}0,0045 \mathrm{mg} / \mathrm{sel} \\
=45 \times 10^{-7} \mathrm{~g} / \mathrm{sel}\end{array}$ & $\begin{array}{l}0,0024 \mathrm{mg} / \mathrm{sel} \\
=24 \times 10^{-7} \mathrm{~g} / \mathrm{sel}\end{array}$ & $\begin{array}{l}0,00028 \mathrm{mg} / \mathrm{sel} \\
=28 \times 10^{-8} \mathrm{~g} / \mathrm{sel}\end{array}$ & $\begin{array}{l}0,00025 \mathrm{mg} / \mathrm{sel} \\
=25 \times 10^{-8} \mathrm{~g} / \mathrm{sel}\end{array}$ \\
\hline
\end{tabular}

Pada tabel 2 perkiraan lipid tertinggi yang dihasilkan tiap satu sel yaitu pada perlakuan Porphyridium sp. pada salinitas $20 \mathrm{ppt}$ sebesar $0,006 \mathrm{mg} / \mathrm{sel}$. Demikian pula perkiraan kandungan lipid per sel mikroalga Isochrysis sp. tertinggi terdapat kultur salinitas 20 ppt.

\section{Pembahasan}

\section{Kepadatan Populasi}

Kepadatan populasi Porphyridium sp. pada salinitas 20 ppt dan 25 ppt lebih cepat mengalami death phase atau fase kematian dibanding Porphyridium sp. pada salinitas yang lebih tinggi yaitu 30 ppt dan 35 ppt. Pada perlakuan Porphyridium sp. dengan salinitas 30 ppt, puncak kepadatan terjadi pada hari ketiga, demikian juga pada perlakuan Porphyridium sp. dengan salinitas 35 ppt, puncak kepadatan terjadi pada hari keempat. Sama halnya dengan perlakuan pada mikroalga Porphyridium sp., pada perlakuan Isochrysis $\mathrm{sp}$. puncak kepadatan juga terjadi pada hari yang berbeda pada masing-masing perlakuan.
Setelah fase puncak, semua perlakuan menunjukkan penurunan populasi hingga masuk ke dalam fase kematian.

Pertumbuhan mikroalga sendiri dipengaruhi oleh beberapa faktor diantaranya nutrien, intensitas cahaya, $\mathrm{CO}_{2}, \mathrm{pH}$, temperatur, serta salinitas yang dibutuhkan dalam proses fotosintesis (Fogg, 1965). Pada awal pengkulturan, nutrien dari pupuk yang diberikan masih tinggi dan dimanfaatkan dengan baik sehingga terjadi peningkatan populasi. Sebaliknya, setelah fase puncak, jumlah populasi mikroalga terus meningkat namun jumlah nutrien tidak mencukupi kebutuhan mikroalga sehingga terjadi persaingan antara mikroalga satu dengan yang lainnya dan mengakibatkan penurunan populasi (Round, 1973).

Selain itu, perbedaan puncak kepadatan ini disebabkan oleh stress osmotik berupa salinitas yang diberikan pada perlakuan. Salinitas yang tidak sesuai dengan salinitas hidup mikroalga yang diberikan pada 
perlakuan ini mempengaruhi tekanan osmosis antara sel dan medium kultur. Media kultur yang bersifat bersifat hipertonis dan hipotonis terhadap sel mikroalga ini mengganggu keseimbangan osmotik sel. Terganggunya keseimbangan osmotik sel ini membuat sel melakukan adaptasi dengan cara penyeimbangan osmotik pada lingkungan dalam sel dan lingkungan luar sel (Erdmann dan Hagemann, 2001). Keadaan ini membuat sel melakukan respon dengan cara menarik ion. Namun pada saat yang bersamaan, penarikan osmotik air dari vakuola terus berlangsung. Hal ini mengakibatkan penyusutan sel dari dinding sel (Hart et al, 1991). Toleransi terhadap perlakuan salinitas yang dilakukan oleh mikroalga ini membuat nutrien yang di dapat dari pupuk conwy kurang terserap dengan baik (Hastuti dan Djunaidah, 1991).

Pada mikroalga Porphyridium sp. hanya pada salinitas 30 ppt dan 35 ppt saja yang menunjukkan kepadatan yang tinggi karena sesuai dengan salinitas normal untuk kultur mikroalga yaitu \pm 32 - 36 ppt (Effendi, 2003). Berbeda dengan mikroalga Isochrysis sp. yang pertumbuhannya cukup tinggi pada semua salinitas. Hal ini karena mikroalga Isochrysis sp. memiliki toleransi yang tinggi pada salinitas (euryhaline). Isochrysis sp. sendiri dapat hidup pada kisaran salinitas 10 - 30 ppt (Sudjiharno, 2002).

\section{Laju Pertumbuhan}

Laju pertumbuhan merupakan tolak ukur untuk mengetahui kecepatan pertumbuhan mikroalga yang dihitung persatuan waktu kultur (Myers, 1995). Laju pertumbuhan pada mikroalga Isochrysis sp. cenderung lebih tinggi dibandingkan dengan mikroalga Porphyridium sp. Hal ini dimungkinkan karena ukuran sel Isochrysis sp. lebih kecil dibandingkan ukuran sel mikroalga Porphyridium sp. sehingga dapat lebih mudah melakukan perbanyakan sel. Menurut Bouterfas et al, (2006), sel yang memiliki ukuran lebih kecil memiliki masa tumbuh yang lebih cepat dibandingkan dengan sel yang berukuran besar. Selain ukuran sel, stress osmotik yang diberikan pada perlakuan mempengaruhi laju pertumbuhan mikroalga. Dalam mempertahankan kelangsungan hidupnya dari keadaan yang ekstrim tersebut, mikroalga cenderung tidak melakukan perbanyakan sel (Schenk et al, 2008).

\section{Kandungan Lipid}

Kandungan lipid dihitung berdasarkan berat kering dan nilai absorbansi dengan spektrofotometri. Kandungan lipid tertinggi pada jenis mikroalga Porphyridium sp. pada perlakuan dengan salinitas 35 ppt, sementara kandungan lipid tertinggi pada jenis mikroalga Isochrysis sp. pada perlakuan dengan salinitas 35 ppt. Perlakuan yang memiliki kepadatan rendah, hasil perhitungan berat kering dan spektrofotometri menunjukkan lipid yang rendah pula. Hal ini menunjukkan bahwa kandungan lipid meningkat seiring meningkatnya kepadatan dan laju pertumbuhan sesuai dengan penelitian yang dilakukan oleh Safitri (2013). 
Pada perhitungan perkiraan kandungan lipid per sel, perlakuan yang menyumbang lipid tertinggi tiap sel nya pada kedua mikroalga adalah pada salinitas 20. Salinitas 20 ppt merupakan salinitas di bawah salinitas hidup mikroalga Porphyridium sp. Pada salinitas ini mikroalga mengalami cekaman yang ekstrim sehingga menghasilkan kepadatan yang rendah. Namun menyumbang kandungan lipid yang cukup tinggi dalam pengukuran per individunya. Diduga mikroalga dalam cekaman osmotik tersebut mempertahankan diri dengan menghasikan lipid pada pertumbuhan secara alami tubuhnya. Pada proses ini pula, pertumbuhan cenderung melambat agar tidak mengeluarkan banyak energi saat beradaptasi (Widianingsih, 2011). Secara alami, dalam kondisi tidak normal atau dalam keadaan stress osmotik yang terjadi, dapat mengganggu keseimbangan osmotik antara lingkungan luar dan lingkungan dalam sel (Erdmann dan Hagemann, 2001). Untuk menghindari keluarnya air maka perlu dibentuk dinding sel yang memiliki kemampuan mempertahankan keluarnya air dari sel. Dalam keadaan ekstrim ini, laju pertumbuhan semakin rendah namun kandungan lipid yang diperoleh semakin tinggi (Duan et al, 2012).

\section{SIMPULAN DAN SARAN}

\section{Simpulan}

Kesimpulan dari penelitian ini adalah kepadatan populasi tertinggi terjadi pada perlakuan Isochrysis sp. pada salinitas 35 ppt. Mikroalga yang menyumbang lipid tertinggi pada tiap selnya adalah
Porphyridium sp. pada salinitas 20 ppt dan Isochrysis sp. pada salinitas 20 ppt. Stress osmotic mempengaruhi kandungan lipid mikroalga.

\section{Saran}

Saran dalam penelitian ini adalah perlu dilakukan penelitian lanjutan dengan pemberian stress osmotik berupa salinitas yang berbeda terhadap mikroalga sejenis maupun dengan jenis lainnya. Selain itu perlu dilakukan penelitian lanjutan tentang uji lipid secara kuantitatif dengan metode yang lebih baik.

\section{DAFTAR PUSTAKA}

Becker, E.W. 1994. Microalgae Biotechnology and Microbiology. New York Cambridge.

Bouterfas, R., M. Belkoura, A. Dauta. 2006. The effects of irradiance and photoperiod on the growth rate of three freshwater green algae isolated from a eutrophic lake. Limnetica, 25(3): 647-656.

Chisti, Y. 2007. Biodiesel From Microalgae. BiotechnologyAdvances, Vol.25.

Davis, C.C. 1951. The Marine Freshwater Plankton. Michigan State University Press. USA.

Duan, X., Ren., Guang., Yue., L.Liu., Zhu., W.Xue. 2012. Salt-induced Osmotic Stress For Lipid Overproduction in Batch Culture of Chlorella vulgaris. AfricanJ. Biotechnol., Vol.11 (27) : 7072-7078.

Effendi, H. 2003. Telaah Kualitas Air Bagi Pengelolaan Sumberdaya dan Lingkungan Perairan. UGM Press. Yogyakarta. 
Erdmann, N and M. Hagemann. 2001. Salt Acclimation of Algae and Cyanobacteria: A Comparison. In: L.C Rai and J.P Gaur. Algal Adaptation to Environmental Stres. Physiological, Biochemical and Molecular Mechanism. Springer-Verlag Berlin Heidelberg. German.pp. 324-350.

Fogg, G.E. 1965. Algal Cultures and Phytoplankton Ecology. The University of Wisconsin Press. Medison.

Hart, B.T., Bailey., P.Edwards., K.Hortle., K.James., and A.Mc Mahon. 1991. A Review of the Salt Sensitivity of the Australian Freshwater Biota. Hydrobiologia 210:105-144.

Hastuti, W dan Djunaidah. 1991. Heavy metal activate Synthesis Of Peptides In Chlamydomonas Reinhardtii, Plant, Physiol, 98: 127 -136.

Kabinawa and Miyamoto. 1994. Cultivation of Algae Cells Chlorella pyrenoidesa. Annual Report of IC Biotech. International Center of Cooperative in Biotechnology, Engineering Faculty of Osaka. Osaka - Japan.

Kawaroe, M. 2010. The Prospect of Marine Microalgae as Biofuel (Oilgae) for Future Alternative of Energy Source. Pusat Penelitian Surfaktan dan Bioenergi Institut Pertanian Bogor. Bogor.

Kawaroe, M., T.Partono., A.Sunnudin., S.W.Sari., $\quad$ D.Agustine. 2010. Mikroalga : Potensi dan Pemanfaatannya untuk Produksi Bio Bahan Bakar. untuk Biofuel. Institut Pertanian Bogor Press. Bogor.

Mudjiman, A.2007.Makananlkan PT. PenebarSwadaya, Jakarta.

Myers, J. 1995. Growth Characteristic Of Algae In Relation To TheProblem Of Mass Culture. Carnigie Institution Of WashingtonPublication, DC.

Odum. 1993. Fundamental of Ecology. W.B. Souders Company. Toronto. 577 pp.
Panggalo, E.S. 2012. Identifikasi Pengaruh Variabel Kultur Pertumbuhan Terhadap Total Lipid Mikroalga Menggunakan Metode Permukaan Respon [skripsi] Universitas Indonesia. Jakarta.

Round, F.E. 1973. The Biology Of Algae. Edward Arnold. 278 pp. London

Safitri, M.E., R. Diantari., Suparmono., dan M. Muhaemin. 2013. Kandungan Lemak Total Nannochloropsis sp. Pada Fotoperiode Yang Berbeda eJurnal Rekayasa dan Teknologi Budidaya Perairan Volume I No 2 ISSN: 2302-3600

Schenk, P. M., Griffiths., and Harisson. 2008. Second Generation Biofuel : High Efficiency Microalgae for Biodesel Production. Bioenergy.

Sleigh, M.A. 1989. Adaptations of ciliary systems for the propulsion of water and mucus. Comp. Biochem. Physiol. 94A:359-364.

Sudjiharno. 2002. Budidaya Fitoplankton dan Zooplankton. Departemen Kelautan dan Perikanan Direktorat Jenderal Perikanan Budidaya, Balai Budidaya Laut Lampung.

Wayan, N.S.A., M.Afriastini., Maulida, Yoana. 2012. Potensi Asam Lemak Dari Mikroalga Nannochloropsis sp. Sebagai Antioksidan Dan Antibakteri. Seminar Nasional XI Pendidikan Biologi FKIP UNS 3-204.

Widianingsih., R.Hartati., E.H.Endrawati., M.Hilal. 2011. Kajian Kadar Total Lipid dan Kepadatan Nitzschia sp. yang Dikultur dengan Salinitas Berbeda. Undip E-Journal 4030-8655-1. 
Pengaruh Pemberian Stress Osmotik ... / 66 